\title{
INFLUENCE OF SODIUM BICARBONATE AND STANDARD ANTIDOTES ON ACID-BASE STATUS IN RATS POISONED WITH DICHLORVOS
}

\author{
Danka Stefanović1, Biljana Antonijević1, Dubravko Bokonjić2 ${ }^{2}$ Miloš P. Stojiljković2 \\ Zoran A. Milovanović2, Mirjana Nedeljković1 \\ IInstitute of Toxicological Chemistry, Faculty of Pharmacy, University of Belgrade, \\ 2National Poison Control Centre, Military Medical Academy, Belgrade
}

\begin{abstract}
Summary: The aim of the present work was to examine potential beneficial role of sodium bicarbonate (3 $\mathrm{mmol} / \mathrm{kg} \mathrm{ip})$ on protective potency of trimedoxime $(10 \mathrm{mg} / \mathrm{kg} \mathrm{im})$, obidoxime $(10 \mathrm{mg} / \mathrm{kg} \mathrm{im})$ and atropine (10 $\mathrm{mg} / \mathrm{kg} \mathrm{im}$ ) in rats poisoned with dichlorvos. Special attention was paid to the influence of co-administration of sodium bicarbonate on acid-base status in experimental animals poisoned with dichlorvos (1.3 LD 50 SC). Coadministration of sodium bicarbonate significantly increased protective effect of standard antidotes in rats poisoned with dichlorvos. Sodium bicarbonate given along with atropine/oxime produced an increase in blood pH value and correction of acidosis. In conclusion, correlation between protective effect and biochemical outcome was evident when sodium bicarbonate was added to antidotes.
\end{abstract}

Key words: dichlorvos, sodium bicarbonate, antidotes, acid-base status

\section{Introduction}

Pesticides are widely used all over the world to protect agricultural and horticultural crops against damage. They are also employed at home and work to assure a pest-free environment. The advantages of the abundant use of organophosphorus (OP) compounds for pest control are paid for dearly, taking into account the some 100000 victims per year world-wide. Mortality is a result of either accidental poisoning or ingestion with suicidal intent (1).

Organophosphorus insecticides (OPIs) inhibit all the esterase type enzymes, but they are specific inhibitors of acetylcholinesterase (AChE, EC 3.1.1.7) and butyrylcholinesterase (BuChE, EC 3.1.1.8) (2). $\mathrm{AChE}$ is enzyme responsible for the destruction and termination of the physiological effect of a neurotransmitter, acetylcholine (ACh). In physiological circumstances ACh is hydrolysed almost immediately by AChE (3). Exposure to organophosphates will cause inhibition of $\mathrm{AChE}$ and accumulation of $\mathrm{ACh}$ at the synaptic cleft of the cholinergic neurons. The resulting

\footnotetext{
$\overline{\text { Address for }}$ correspondence

Danka Stefanović

Institute of Toxicological Chemistry

Faculty of Pharmacy, Vojvode Stepe 450, 11221 Belgrade
}

phosphorylated enzyme is very stable and significant spontaneous regeneration of the active enzyme is not observed. Therefore, regeneration of the AChE activity mainly depends on the synthesis of new molecules (4). The typical features of OP poisoning are those of cholinergic poisoning and may be conveniently divided into muscarinic (rhinorrhea, bronchoconstriction, hypersalivation, lacrimation, urinary and faecal incontinence, abdominal cramps, bradycardia, hypotension, miosis), nicotinic (hypertension, tachycardia, muscle fasciculation, necrosis of sceletal muscules) and central effects (anxiety, headaches, convulsion, central respiratory depression, coma and death) (5-7).

Standard therapy of OP poisoning is based on the administration of atropine and oxime as specific antidotes $(8,9)$. While atropine antagonizes muscarinic symptoms, both peripheral and central, a little effect can be seen at nicotinic receptor sites. Oximes are well recognized as reactivators of inhibited AChE. However, at least three mechanisms are involved in complete antidotal effect of oximes: (a) the most important action is reactivation of the inhibited enzyme, (b) given in higher doses, oximes reversibly inhibit the enzyme protecting thus the still uninhibited $\mathrm{AChE}$ and (c) they also posses ability to react directly with organophosphates. Reactivation of the inhibited AChE is a process of its dephosphorylation. In the early 
phase of this process specific orientation of an oxime toward the active center of enzyme occurs. Later on, an intermediary complex oxime-phosphorylated enzyme is created, leading to a nucleophilic attack toward phosphorus atom attached to the active site of the enzyme. This oxime-OP complex is then split off, leaving the regenerated enzyme (10-12).

Despite the fact that effects of OPs were extensively investigated and well documented, there is still a wide range of problems concerning therapeutic approaches to the OP poisoning. Until today, oxime that possesses properties of a »universal $\ll$ AChE reactivator has not been synthesised. Therefore, oximes are not equally effective in antagonizing the toxicity of structurally different OPs. It has been shown that among the currently used oximes trimedoxime (TMB4) (1,3-bis-(4-hydroxyiminomethyl-pyridinium)-1-propane dichloride) and obidoxime (LüH-6) (bis-(4-hydroxyiminomethyl-pyridinium)-1-methylether dichloride) are very efficient antidotes in poisonings caused by the majority of OP insecticides (13). During the last few years further improvement of the therapy was also made with the introduction of sodium bicarbonate. It was reported that administration of sodium bicarbonate potentiated therapeutic activity of atropine in acute OP poisonings (14-17).

In that respect the aim of the present work was to examine potential beneficial role of sodium bicarbonate on antidotal potency of trimedoxime, obidoxime and atropine in rats poisoned with OP insecticide dichlorvos (DDVP) (O,O-dimethyl-O-(2,2-dichlorvinyl)phosphate). Additionally, special attention was paid to the influence of co-administration of sodium bicarbonate on acid-base status in experimental animals treated with DDVP.

\section{Material and Methods}

Chemicals. Dichlorvos was purchased from CIBA, Basel, Switzerland. Trimedoxime and obidoxime were obtained from the Military Medical Institute, Belgrade. The pyrite of tested oximes was analyzed by HPLC technique and it was greater than 99\%. Atropine sulphate was purchased from Sigma Chemical Company, St. Louis, MO, USA. All the other chemicals of analytical grade were purchased from the commercial sources. Stock solution of dichlorvos was prepared in isopropanol. Oximes were dissolved in distilled water and diluted to the required concentration immediately before use.

Animal experiments. Males Wistar rats (180$240 \mathrm{~g})$ were obtained from the Military Medical Academy, Belgrade. Experimental animals were acclimatised for at least one week prior to use and received food and tap water ad libitum.

In order to examine protective effect of a specific antidote five groups of experimental animals $(n=8$ per group) were poisoned subcutaneously (sc) with increasing doses of dichlorvos. Immediately thereafter rats were treated with atropine $10 \mathrm{mg} / \mathrm{kg} \mathrm{im}$, oximes $10 \mathrm{mg} / \mathrm{kg} \mathrm{im}$ and sodium bicarbonate $3 \mathrm{mmol} / \mathrm{kg}$ ip. These antidotes were administered either as single regimens or in combinations. After the 24-hours survival registration, median lethal doses $\left(\mathrm{LD}_{50}\right)$ were calculated according to the method of Litchfield and Wilcoxon (18) with $95 \%$ confidence limits. Protective indices (PIs) were calculated according to the following equation:

$$
\mathrm{PI}(\text { antidote })=\frac{\mathrm{LD}_{50}(\mathrm{DDVP}+\text { antidote })}{\mathrm{LD}_{50}(\mathrm{DDVP})}
$$

In the biochemical sets of experiments $\mathrm{pH}$ and concentration of bicarbonate anion in arterial blood were measured by the Blood Gas Analyzer - BGM (model IL 1312), Instrumentation Laboratory, Lexington, USA. Arterial blood samples were drawn by intracardial puncture using heparinised syringe and kept on ice until analyzing. In the first part of biochemical experiments, aimed to find out (optimal) time interval relevant for the assessment of acid-base status, arterial blood samples were collected 10, 20 and 30 min after the administration of $\mathrm{NaHCO}_{3} 3$ $\mathrm{mmol} / \mathrm{kg}$ ip.

Within the second part of biochemical experiments, when the time period between the application of tested substances and arterial blood sampling was fixed at 10 minutes, rats were poisoned with dichlorvos $1.3 \mathrm{LD}_{50} \mathrm{SC}$ and immediately thereafter treated with atropine $10 \mathrm{mg} / \mathrm{kg} \mathrm{im}$, oximes $10 \mathrm{mg} / \mathrm{kg} \mathrm{im}$ and sodium bicarbonate $3 \mathrm{mmol} / \mathrm{kg}$ ip either as single regimens or in combinations.

Data analysis. Statistical significance was determined by means of Student's t-test and Mann-Whitney U-test, and differences were considered significant when $\mathrm{p}<0.05$, $\mathrm{p}<0.01$ and $\mathrm{p}<0.001$.

\section{Results}

Co-administration of sodium bicarbonate significantly increased the protective effects of standard antidotes in rats poisoned with dichlorvos (Table I). Addition of bicarbonate increased PIs of atropine, trimedoxime and obidoxime 1.72, 2.27 and 2.07 times, respectively. Obidoxime given alone ensured better protection of experimental animals then trimedoxime, i.e. PI value of obidoxime was 2.59 times greater than that of trimedoxime.

Blood $\mathrm{pH}$ and bicarbonate anion concentration were extremly affected 10 min after sodium bicarbonate injection (Table II). This time interval was then used as fixed time throughout the second sets of experiments. 


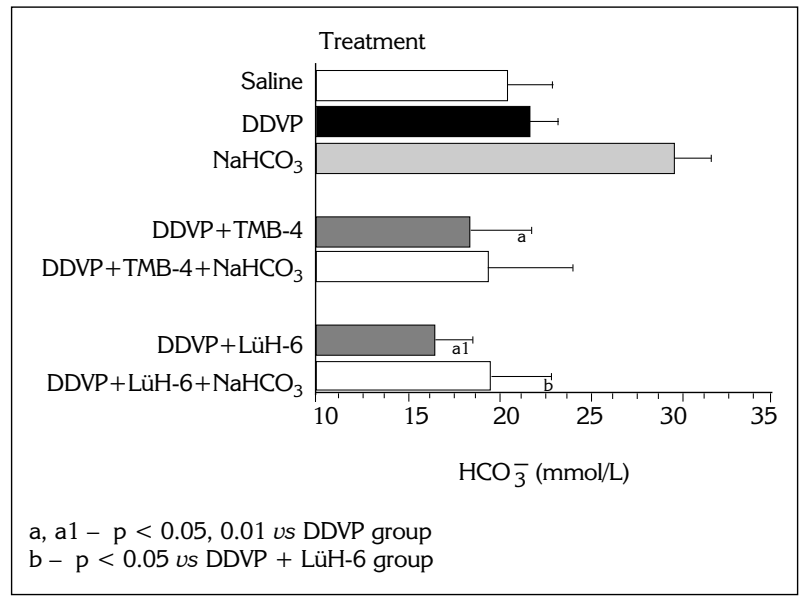

Figure 2. Influence of antidotes on bicarbonate anion concentration in arterial blood of rats poisoned with DDVP. Concentration of bicarbonate anion was measured 10 min after the treatment.

\section{Discussion}

Animal studies previously published suggested that sodium bicarbonate therapy favorably decreased mortality rate in organophosphate poisonings (15, 16). Bajgar et al. (15) examined potential beneficial role of sodium bicarbonate $(3 \mathrm{mmol} / \mathrm{kg} i p)$ in rats intoxicated with $2 \mathrm{LD}_{50} S C$ of sarin, dichlorvos or pyridostigmine. It was reported that administration of bicarbonate had therapeutic effect in organophosphate and pyridostigmine intoxications, even more when combined with atropine. The results obtained in our study are in agreement with those published earlier, since co-administration of sodium bicarbonate significantly improved protective effect of atropine as well as of the oximes (trimedoxime and obidoxime) used as antidotes in poisoning caused by dichlorvos (Table I).

Clinicians also reported successful management of OP intoxicated patients by using infusions of sodium bicarbonate $(14,16,17)$. In the study published by Balali-Mood et al. (14), patients with known OP poisoning (manly suicide) were treated intravenously with atropine plus sodium bicarbonate $(3 \mathrm{mEq} / \mathrm{kg}$ over one hour, followed by $3 \mathrm{mEq} / \mathrm{kg}$ in $1 \mathrm{~L}$ of dextrose per day until recovery/death). According to the clinical outcome, authors concluded that sodium bicarbonate could be usefull as a part of therapeutic regimen in human OP poisoning. Further study of the same group of authors (constant infusion of sodium bicarbonate, $5-6 \mathrm{mEq} / \mathrm{kg}$ in one hour, followed by $5-6$ $\mathrm{mEq} / \mathrm{kg}$ in the next 23 hours and the same amount every day until recovery/death) showed that high doses of sodium bicarbonate significantly decreased the total atropine dose used in patients acutely poisoned with OP pesticides (17).

Early findings on this topic (19) demonstrated that bicarbonate pretreatment along with standard therapy in rats poisoned with diisopropil fluorophos- phate appreciably enhanced the therapeutic efficacy of pralidoxime chloride, with the shift of PI from 7.63 to 11.7. In order to explain the mode of action of bicaronates, the same authors also investigated pharmacokinetic properties of pralidoxime proving that bicarbonate application led to a significant increase in oxime distribution into the tissue compartment. Having in mind these facts, it could be assumed that the enhancement of the appearent distribution volumes of oxime in central and peripheral compartments would induce better reactivation of inhibited $\mathrm{AChE}$ in target tissues. However, introduction of sodium bicarbonate did not improve either trimedoxime or obidoxime reactivating potencies in rats poisoned with dichlorvos, i.e. significant increase in brain, diaphragmal and erythrocyte AChE activities was not obtained in our previous experiments (20).

In severe OP poisoning among the other clinical manifestations appearance of a life-threatening respiratory depression followed by the oncet of dyspnoea and apnoea produces acid-base disturbances i.e. acidosis (13). In our study dichlorvos produced a decrease in the blood $\mathrm{pH}$ value, while bicarbonate anion concentration was almost as in the control group (Table III). Previous studies using domestic pigs percutaneously exposed to VX have demonstrated statistically significnt elevation in $\mathrm{K}^{+}$, inorganic phosphates, $\mathrm{pCO}_{2}$ and $\mathrm{tCO}_{2}$, that occurred at the time of apnoea as well as the decrease in arterial blood $\mathrm{pH}$ (21). Bicarbonate anion concentration and blood $\mathrm{pH}$ value observed in atropine treatment did not correlate with its protective efficacy (Tables I, III). However, good correlation between protection and biochemical outcome was evident when sodium bicarbonate was added to atropine.

Trimedoxime and obidoxime, known as potent reactivators especially in OP insecticide intoxications $(22,23)$, led probably via indirect pathway to the correction of acidosis produced by DDVP (Figure 1). In these treatments as a part of compensatory mechanisms depletion of bicarbonates was also detected (Figure 2). Addition of $\mathrm{NaHCO}_{3}$ to both oximes provided better protection (Table $I$ ) and reversal of induced biochemical changes in rat arterial blood (Figures 1, 2).

Most of the OPs are hydrolysed more rapidly at an alkaline $\mathrm{pH}$. Beneficial action of sodium bicarbonate could be at least explained by the change in the rate of hydrolyses of $\mathrm{OP}$ relative to blood $\mathrm{pH}$ thus inducing increase of elimination rate. On the other hand, correction of acidosis as a supportive measure appeared to be valuable procedure that potentiated antidotal properties of currently used antidotes. To find the exact mechanism of sodium bicarbonate action, further experiments are required.

Acknowledgment: This work was supported by grant 1432 from the Ministry of Science, Technology and Development, Republic of Serbia. 


\title{
UTICAJ NATRIJUM BIKARBONATA I STANDARDNIH ANTIDOTA NA ACIDO-BAZNI STATUS PACOVA TROVANIH DIHLORVOSOM
}

\author{
Danka Stefanović1, Biljana Antonijević1, Dubravko Bokonjić2, Miloš P. Stojiljković2 \\ Zoran A. Milovanović ${ }^{2}$, Mirjana Nedeljković1 \\ IInstitut za toksikološku hemiju, Farmaceutski fakultet, Beograd \\ 2Nacionalni centar za kontrolu trovanja, Vojnomedicinska akademija, Beograd
}

\begin{abstract}
Kratak sadržaj: Cilj rada je bio da se ispita efekat natrijum bikarbonata ( $3 \mathrm{mmol} / \mathrm{kg}$ ip) na zaštitni potencijal trimedoksima (10 mg/kg im), obidoksima $(10 \mathrm{mg} / \mathrm{kg} \mathrm{im}) \mathrm{i}$ atropina $(10 \mathrm{mg} / \mathrm{kg} \mathrm{im}) \mathrm{u}$ pacova trovanih dihlorvosom. Posebna pažnja je posvećena uticaju kombinacija natrijum bikarbonata i antidota na acido-bazni status eksperimentalnih životinja trovanih dihlorvosom $\left(1.3 \mathrm{LD}_{50}\right)$. Primena kombinacija sa natrijum bikarbonatom značajno je povećala zaštitne efekte standardnih antidota, a došlo je i do porasta vrednosti pH krvi i korekcije acidoze. Takođe, moglo se zaključiti da kada je natrijum bikarbonat dat zajedno sa atropinom/oksimom postoji jasna korelacija između dobijenih zaštitnih efekata i testiranih biohemijskih parametara.
\end{abstract}

Ključne reči: dihlorvos, natrijum bikarbonat, antidoti, acido-bazni status

\section{References}

1. Karalliedde L, Eddleston M, Murray V. The global picture of organophosphate insecticide poisoning. In: Karalliedde L, Feldman S, Henry J, Marrs T, editors. Organophosphates and health. London: Imperial College Press, 2001: 431-73.

2. Aldridge WN, Reiner E. Enzyme inhibitors as substrates: interactins of esterases with esters of organophosphorus and carbamic acids. In: Neuberger A, Tatum EL, editors. North-Holland research monographs frontiers of biology, vol. 26. Amsterdam, London: North-Holland Publishing Company, 1972.

3. Taylor P. Anticholinesterase agents. In: Hardman JG, Limbird LE, Molinoff PB, Ruddon RW, Gilman AG, editors. Goodman and Gilman's The pharmacological basis of therapeutics. ${ }^{9}$ th edition. New York: McGrawHill, 1996: 161-76.

4. Reiner E, Pleština R. Regeneration of cholinesterase activities in humans and rats after inhibition by O,Odimethyl-2,2-dichlorvinyl phosphate. Toxicol Appl Pharmacol 1979; 49: 451-54.

5. Namba T, Nolte CT, Jackrel J, Grob D. Poisoning due to organophosphate insecticides. Acute and chronic manifestations. Am J Med 1971; 50: 475-92.

6. Briggs CJ, Simons KJ. Recent advances in the mechanism and treatment of organophosphorus poisoning. Pharm Int 1986; 7: 155-59.

7. Rivett K, Potgieter PD. Diaphragmatic paralysis after organophosphate poisoning. S Afr Med J 1987; 72: 881-82.

8. Leadbeater L. When all else fails. Chem $\mathrm{Br} 1988 ; 24$ (7): 683-86.

9. Dunn MA, Sidell FR. Progress in medical defense against nerve agents. J Am Med Assoc 1989; 262 (5): 649-52.
10. De Jong LPA, Wolring GZ. Inhibition of acetylcholinesterase by $\mathrm{N}$-alkylpyridinium-2-aldoxime salts. Croat Chem Acta 1975; 47: 383-91.

11. De Jong LPA, Wolring GZ. Effect of 1-(ar)-2-hydroxyiminomethyl-pyridinium salts on reactivation and aging of acethylcholinesterase inhibited by ethyl dimethylphoshoramido-cyanidate (Tabun). Biochem Pharmacol 1978; 27: 2229-37.

12. Markov M, Maksimović M, Binenfeld Z. Direktna reakcija piridinskih oksima sa organofosfornim jedinjenjima. Arh Hig Rada Toksikol 1984; 35: 263-68.

13. Bismuth C, Inns RH, Marrs TC. Efficacy, toxicity and clinical use of oximes in anticholinesterase poisoning. In: Ballantyne B, Marrs TC, editors. Clinical and experimental toxicology of organophosphates and carbamates. Oxford: Butterworth-Heinemann, 1992: 555-77.

14. Balali-Mood M, Shahab-Ahmadi A, Salimifar M, Shariate $M$. Effects of sodium bicarbonate in human organophosphate poisoning [abstract]. Chemical and Biological Medical Treatment Symposium III; 2000 May 7-12; Spiez, Switzerland: 26.

15. Bajgar J. The treatment of intoxication with selected organophosphates and a carbamate: comparison of different therapeutic approaches. Proceedings of CBMTSIndustry II, World Congress on Chemical and Biological Terrorism: 2001 Apr 22-27; Dubrovnik, Croatia. 2001: 180-84.

16. Karalliedde L, Szinicz L. Management of organophosphorus compound poisoning. In: Karalliedde L, Feldman S, Henry J, Marrs T, editors. Organophosphates and health. London: Imperial College Press, 2001: 257-94.

17. Balali-Mood M, Ayati MH, Ali-Akbarian H. Effects of high doses of sodium bicarbonate in acute organophospate pesticide poisoning [abstract]. Chemical and Biological 
Medical Treatment Symposium IV. 2002 Apr-May 28-3; Spiez, Switzerland: 15.

18. Litchfield JT, Wilcoxon F. A simplified method of evaluating dose-effect experiments. J Pharmacol Exp Ther 1949; 96: 99-113.

19. Jeevarathinam K, Ghosh AK, Srinivosan A, Das Gupta S. Pharmacokinetics of pralidoxime chloride and its correlation to therapeutic efficacy against diisopropyl fluorophosphate intoxication in rats. Pharmazie 1988; 43: $114-15$.

20. Antonijević B, Stefanović D, Milovanović ZA, Stojiljković MP, Bokonjić B, Đukić M. Standard antidotes along with sodium bicarbonate in organophosphate poisoning [abstract]. Chemical and Biological Medical Treatment Symposium IV; 200228 April - 3 May, Spiez, Switzerland: 14.

21. Chilcott RP, Dalton CH, Hill I, Davidson CM, Blohm KL, Hamilton MG. Clinical manifestacins of VX poisoning following percutaneous exposure in the domestic white pig. Hum Exp Toxicol 2003; 22: 255-61.

22. Jokanović M, Maksimović M. A comparison of trimedoxime, obidoxime, pralidoxime and HI-6 in the treatment of oral organophosphorus insecticide poisoning in the rat. Arch Toxicol 1995; 70: 119-23.

23. Antonijević B. Antidotal efficacy of oximes. Andrejević K, editor. Beograd: Zadužbina Andrejević, 2001: 115.

Received: November 14, 2003

Accepted: December 18, 2003 